\title{
Impact on Income Farmer Debt Bondage System Cengkeh (Case Study in Liwutung Village Pasan District Southeast Minahasa Regency)
}

\author{
Nelson Kario $\mathrm{H}^{*}$ \\ Department of agriculture, Institute for Agricultural Technology, Indonesia
}

Submission: March 13, 2017; Published: April 05, 2017

"Corresponding author: Nelson Kario H, Institute for Agricultural Technology (BPTP) East Nusa Tenggara, Jl Timor RayaKm 32 Naibonat, Kupang, Indonesia. Email: kario_nelson@yahoo.co.id

Abstract

Until recently known as the clove plantation crop that can provide the greatest revenue among plants cultivated population in South east Minahasa Regency. Although the level of selling price per kilo of dry high compared to most other plantation crops among the results, but the reality in practice is still a lot of farmers who still fall into the practice of debt bondage system that is very detrimental to farmers. The purpose of this research is:

a. Knowing the dynamics of debt bondage system applicable at the farm level.

b. Assessing the value of the losses suffered by farmers with their debt bondage system.

Research was conducted during 3 months from July to September 2015. The location is determined purposive sampling with consideration as production centers. Respondents were selected by 20 farmers. Data collected included primary and secondary data. The data type for the primary data are: recording made by every owner of the garden at the time of measurement of the crop in the form of a notebook crops and types of other expenses such as shopping lists staple for the harvest progresses, wages harvest, pre-harvest such as ladders, rope as media binder stairs and media container yields while secondary data obtained from the department or the relevant authorities are technically fully understand the business development of the crop. The data were analyzed descriptively. The results showed that the source of bonded labor system is productive cycle, farmers' lack of funds to finance farming, relatively high maintenance costs as well as costs of urgency needs of school children especially in the beginning of the new school/college or religious holidays. The amount of bonded labor is determined by the length of time the next harvest or the condition indicator ovary. Great value losses experienced by farmers is Rp. 8,122,056.25 per harvest period.

Keywords: Boundage; Losses; Clove

\section{Introduction}

Clove is one of the plantations of highly dependable government in increasing the national income is mainly derived from the cigarette tax. The revenue contribution can be seen from the large cigarette excise tax that is produced can reach Rp.23.2 trillion [1]. Currently, the needs of cloves in the country reached 110 thousand tons per year. Of these 93 percent of the crop was purchased by the industry as a mixture of clove cigarettes [2]. Therefore it is not surprising that the clove cigarette factory becomes the single largest consumer of cloves users. In line with the still fairly high demand for fruit clove affect the development of farming which is characterized by the growing folk back clove plantations. Still quite dominant clove plantation developments such as the impact of higher selling prices.

Based on the monitoring of price developments in some areas the production of cloves in Indonesia generally have levels of selling prices were quite high but varied among others: Aceh between Rp.105,000 - Rp.130,000per kg, Bali Rp.100,000per kg [2] and East Java Rp.110,000-130,000per kg. Panca, (2016) says that in line with increased selling prices significantly expand the area eventually sparked many clove plantations whether conducted through its own 
efforts and the help of outsiders. One program outside help farmers is: Hub project and Clove Intensification System (CIS) launched since 2013 with the aim of supporting increased productivity cloves in Indonesia by providing full support in terms of input supply, agricultural training and infrastructure development. Until now there are 21 locations in clove production centers in Indonesia. (sampoerna.com, 2016).

Puslitbun (2007) says that there are four varieties of cloves namely: siputih, zangsibar, ambon and zanbon (clove composite). Nationally, the area of commodities clove until now has reached about 400 thousand hectares of productive land area of 300 thousand hectares, (Panca. 2016). Relation to the development of existing farming [3] reported this farm should be developed because they have a value of $\mathrm{R} / \mathrm{C}$ ratio ranged from 4.90 to 6.94 with the ROI is 390-598. Therefore, the clove farming is feasible to be developed as it has the value of $\mathrm{R} / \mathrm{C}$ ratio $>1$ and the efficiency of capital usage. Based on the user benefits from the fruits of cloves, among others, besides a main source to serve as the manufacture of cigarettes is also capable of ridding the body of toxins and harmful microbes, protecting the damage caused by cells in the body, helping to stimulate the production of energy in all parts of the body, heal the sick gear, mosquito repellent, anti-inflammatory, digestive problems, a healthy digestive system, helps men in terms of sexual and prevent colds or influenza can also be used as an anthelmintic and anesthesia [4,5]. while by-products such as dried clove oil can be used as raw materials of pharmaceutical industry, food flavorings and fragrances [5]. North Sulawesi (Sulawesi) has been very well known as one of the potential for being a production center because it has been able to provide a substantial contribution to the income of farmers. This is most apparent in Table 1.

Table 1: Development of production and the selling price of cloves in the level of farmers in North Sulawes (2008-2013).

\begin{tabular}{|c|c|c|}
\hline Year & Production (Ton) & Price (Rp) \\
\hline 2008 & 461 & 55,000 \\
\hline 2009 & $1,663.00$ & 34,000 \\
\hline 2010 & $20,166.00$ & 40,000 \\
\hline 2011 & 338.93 & 170,000 \\
\hline 2012 & 327 & 120,000 \\
\hline 2013 & & 145,000 \\
\hline
\end{tabular}

From Table 1 shows that production is generated during the time span from 2008 to 2013 is quite varied with the highest production in 2010 reached 20,166 ton in 2009 followed by 1,663 tons while others $<1,000$ ton. Similarly to the sales price achieved is the highest reached Rp.170,000kg that occur after 2011. Some of the main challenges is the development of farming sustainability of natural resources, climate change and the decline in factor productivity. Besides the downward trend in the size of land holding is a serious challenge to the profitability of agriculture [6].

Southeast Minahasa (Mitra) is known as one of the districts of considerable potential in North Sulawesi in contributing to the production of next Minahasa and Bolaang Mongondow. This is apparent from the development of farming are still very dominant cloves. BPS, (2015) reported that the total area of the development of cloves in the District Partners covering 5,375.85 ha distributed over $1,240.29 ; 3,892.96$ ha immature produce and 242.6 do not produce (damaged). In line with the development of farming, the bonded labor system is one of the dynamics which influenced the income of farmers clove especially at harvest time. This condition is noteworthy because it is very detrimental phenomenon due to the farmers only receive income in very small amounts as a result suffered a loss that ultimately affect the financing, the development of farming and the cost of daily living. Therefore, it has carried out research aimed at:

a. Knowing the dynamics of debt bondage system applicable at the farm level.

b. Assessing the value of the losses suffered by farmers with their debt bondage system.

\section{Research Methodology}

Research carried out for 3 months i.e from July to September 2015. The research location is determined intentionally (purposive sampling), the Liwutung One village Pas an districts which is a regional production center. The number of respondents who selected farmers by 20 farmers who harvest cloves. Data collected included primary and secondary data. The data type for the primary data are: recording made by each owner of the garden at the time of measurement of the crop in the form of a notebook crops and types of other expenses such as shopping lists staple for the harvest progresses, wages harvest, pre-harvest such as ladders, rope as media binder stairs and media container yields while secondary data obtained from the department or the relevant authorities are technically fully understand the business development of the crop. The data were analyzed descriptively [7].

\section{Results and Discussion}

\section{Bonded system applicable to operations at minahasa clove harvest}

Understanding Bonded by Indonesian dictionary are loans granted to farmers, fishermen or small businesses which payment is made to the yields or production by poor prices. Bonded usually occurs due to urgency of farmers to meet the needs of everyday life. The types of needs associated with debt bondage system is usually the primary or the absolute, the numbers are quite large and are in cash.

Until now bonded labor is one form of lending and borrowing system that applies in almost all lines of business agriculture. A form of borrowing that do usually in the form of cash that will be returned in the form of goods in this case the yield of agricultural commodities. This type of business is long-standing in the midst of everyday life peasants even more detrimental to their own but these losses tend to be regarded as normal due to the urgency of subsistence. According [8] have bonded labor system in the farming clove is considered normal for many indigenous communities who 
practiced in many plant crops such as cloves in North Sulawesi in Minahasa, Sangihe Talaud, Ambon (Maluku) and Central Sulawesi. Area production center of this system is a tradition that has been done in the form of agreements that are normally associated with buying and selling crops or selling fruit with cloves. Therefore, the agreement in the bonded labor system is already included in the Minahasa culture oldest such Mapalus [9].

Agreements usually done between farmers and traders when see the plant has shown any indication of vegetative and generative growth that will bear fruit within the next 6 months. Farmers as owners usually look for or offer to ordinary traders who buy and sell the capital. The meeting between traders and farmers is very synonymous with the supply and demand which resulted in an agreement of sale and purchase transaction but still within the bounds of reasonableness, or in other words mutually beneficial. It is important to remember the form of the transaction model is not regulated in the Act.

\section{Characteristic of respondents}

Table 2: Characteristic farmer respondents.

\begin{tabular}{|c|c|c|c|c|}
\hline No & Component & Unit & Amount & The Range \\
\hline 1 & Age & Year & 53.05 & $38-68$ \\
\hline 2 & Education & Year & 9.85 & $6-18$ \\
\hline 3 & $\begin{array}{c}\text { The Number of } \\
\text { dependents }\end{array}$ & Soul & 1.6 & $0-4$ \\
\hline 4 & Experience & Year & 36.35 & $15-51$ \\
\hline 5 & Large & Ha & 1.29 & $0,8-225$ \\
\hline 6 & $\begin{array}{c}\text { The Number of } \\
\text { Persil }\end{array}$ & Place & 1.65 & $1-3$ \\
\hline 7 & $\begin{array}{c}\text { The Number } \\
\text { of productive } \\
\text { plants } \\
\text { Proportion of } \\
\text { plants: }\end{array}$ & Tree & 158 & $85-240$ \\
\hline & $\begin{array}{c}\text { Local } \\
\text { Variety }\end{array}$ & Percent & 24.36 & \\
\hline & $-\quad$ Zangsibar & Percent & 75.64 & \\
\hline
\end{tabular}

Characteristic respondent is required to determine the extent of the resource potential of internal support that farmers had helpful in supporting the implementation and development of the business. Table 2 shows that the age of the respondent farmers still on productive criteria, despite being on the verge of unproductive (55 years old). Therefore, the picture indicates the farm is plagued with labor because of the potential labor force in the family is constrained age, the job is interrupted or need help labor sourced from outside. Therefore, for the development of farming is to the better, advanced and productive, the farmer is an absolute need support greater costs, especially the money that is used in cash for finance workers coming from outside the family considering the type of farming is classified as the type of farming solid capital. Formal education achieved average farmer just graduated from high school (9.85\%). Educational attainment on clove farmers can be said to be better because generally rural farmers in the average primary school do not graduate school not even at all cause high levels of illiteracy at the level of village farmers. This aspect must be considered absolute, especially in supporting the successful implementation of the farm is mainly related to the speed of innovation adoption because until now there's been a lot of advanced innovations being introduced to farmers through both formal and non-formal media but less adopted or develop properly. One reason is the low level of education of farmers.

To experience known to be one of the critical success factors of farming as it relates to the quality of use of production facilities and measures anticipatory especially in anticipation of the obstacles encountered. From Table 2 it appears that the length of experience in the development of farming clove farmers can be said is long enough. Therefore, the cloves have a quality farm farming better than similar types of farm commodities as farmers in the region have had a long experience in dealing with the constraints of farming cloves. One solutions that do include exchanging experiences overcome pests/ diseases like caterpillars that attack the stem cloves, and others. The land area is medium size farms to be done. The importance of this aspect because it is correlated with the amount of financing means of production such as labor, fertilizer, seeds and pesticides and others. The more land that farmers have greater opportunities to raise revenue rather than just have a small land area, but if one manages this land there will be inefficient utilization of the budget due to incorrect prediction time allocation outpouring of financing.

The number of productive clove plant is one indicator of success because it includes an annual plant that empirically dire need of attention, especially treatment that can produce well. The plants will produce well they are maintained too well through optimalization resource use of existing support and vice versa, the plant will not produce well if not adequately supported by the level of maintenance of the plants a good result is not optimal maintenance affecting crops such as damage or death. From Table 2 appears that the number of plants that are able to produce is an average of 158 trees. Seeing this number, it can be said that farmers have been able to develop this clove farming is well characterized by the high number of plants which production has reached 75.64 percent, while the proportion of plants that did not produce only the remaining 24.36 percent.

\section{System implementation bonded}

In this clove farming system mechanisms longstanding debt bondage once, especially when started development of business, especially as we enter the productive phase. Opportunities bonded labor system is very open at the farm level clove caused by several factors, among others:

a. Relatively long productive cycle reaches 4-5 years other hand there are periods of low production and farmers need to budget for living expenses.

b. Maintenance costs are relatively high.

c. Absolute urgency financing needs such as school children, the sick, a family event, the cost of farming labour, etc. 
This debt bondage occurs when farmers in dire need of funds that are cash. Usually the money lenders are traders, employees or fellow farmers who have substantial funds. The timing of the transaction is relatively dependent bondage time when the funds it needed people who do bonded. The time usually has the highest proportion of demand when entering the new school year in children enter school or college or face religious holidays such as Christmas eve. The value of the transaction depends on the length of time of harvest. The longer the time of harvest, the value transactions getting smaller, and vice versa if it is getting close to harvest the bonded transaction value is likely to be even greater. Usually used as indicators of the transaction is raw fruit crops or dried. Returns in dry form intended for the moneylenders are not bothered anymore with additional work or fear of loss due to the harvest season sometimes happens to coincide with the rainy season so that when agreements are transactions conducted in the form of raw fruit (raw material) it is necessary to additional costs resulting in trader's profits become smaller. If the period of harvest time is still quite long (8-10 months), the deal value of transactions typically between 10 percent to a maximum of 20 percent, and vice versa when the harvest season the rest of the 1-2 months, the amount of the transaction value of bonded labor will be greater and its value reaches a maximum of 80 percent of the real selling prices in the market.

Returns bounded usually held to coincide with the completion of the harvest season. This activity is usually done by the people who do bonded (farmers) while the moneylenders usually tends to be a wait. If within a period of 1-2 months after completion of harvest has been no indication of the recipient bondage want to bring back some fruit clove agreed upon commitments, then the giver will charge directly bonded. What is interesting in this return is when the people who do bonded returns on time and in numbers that commitment then the people who do bonded will be awarded a gift/rewards as motivators to further strengthen the relationship like money or goods. Returns this model usually occurs bonded labor system that has little value (between 10 to 50 kilograms of dried cloves) whereas $>50 \mathrm{~kg}$ is usually done in stages.

\section{Farmer benefits to people who do bonded}

Table 3: Benefits of bonded labor system on farmers

\begin{tabular}{|c|c|c|}
\hline No & Perception & Amount (\%) \\
\hline 1 & Farmyng cost & 15 \\
\hline 2 & Cost of daily living & 15 \\
\hline 3 & Buy cattle & 5 \\
\hline 4 & Bussines & 10 \\
\hline 5 & School children & 30 \\
\hline 6 & $\begin{array}{c}\text { Events marriage } \\
\text { family }\end{array}$ & 10 \\
\hline 7 & Buy farm equipment & 5 \\
\hline 8 & $\begin{array}{c}\text { Transportation/mean } \\
\text { of transport }\end{array}$ & 10 \\
\hline
\end{tabular}

The benefits of this system of bonded labor as contained in Table 3 below are quite varied between 5-30 percent with a high of 30 percent, which is used to finance school need existing family members, while the other needs such as finance day-farming and living costs today only 15 percent. From this utilization shows that the needs related to non technical farming such as the financing of school children do not correlate directly with farming can become a major factor causing the system process doing bonded in large scale not only in the region Partners but also a long-standing, especially in the areas of production centers clove like districts Minahasa, South Minahasa as the center and the largest producer in North Sulawesi. The overall picture shows that the fulfillment of the daily needs of the family members and cash is a major factor in the creation of a system of bonded labor is not related to the success of farming and management itself.

Some off-farm factors that helped influence the occurrence of bonded labor system are: finance the needs of everyday life, ceremonial occasions family members/the marriage and to fund business interests together three each by 10 percent.

\section{Returns bonded}

Bonded known as a business that is very detrimental to farmers. Said to be very harmful because usually giver bonded only appreciate the value of production is very low. As was the case in other commodities, in determining the amount of the transaction value of debt bondage is usually correlated with the length of fruit trees where the longer the plants bear fruit, the value of debt bondage will be smaller, whereas the closer the season reaping the value of the transaction will be of great value as appreciated bigger but remain the same as the market price of cloves fruit when the transaction took place. Some things that are usually used as indicators of assessing the feasibility of giving bonded to the receiver bounded clove fruit are:

\section{Planting conditions}

Bonded labour will be provided by the moneylenders when planting conditions have been shown to have been producing well. It is seen in addition apparent from household conditions routinely harvesting every year, as well as from information sourced from fellow farmers. Volume corelated with the amount of debt bondage with planting conditions. The better planting the cloves then bonded amount to be awarded will be greater but the conversion value per $\mathrm{kg}$, the same as other farmers.

\section{Level of confidence}

Although farmers have a pretty good crop, but his good name has been tarnished as a result often do not pay off for cheating/ outsmart merchants then bonded labor will not be given, but on the contrary if they always keep its promise on time then bonded labor will always be given. Furthermore, for those who do not return the fully bonded several conditions commonly used as reason for the delay in paying off bondage as shown in Table 4. The Major reason major non-fulfillment of repayment obligations of bonded labor is 
dominated by reason of installments of $30 \%$, followed by the reason plants are not producing in line with expectations (less) and will pay off when the production lot with each of $25 \%$. While others tend to be no more than $10 \%$.

Table 4: The reason farmers do not return the appropriate commitment bonded.

\begin{tabular}{|c|c|c|}
\hline No & Perception & Amount (\%) \\
\hline 1 & $\begin{array}{c}\text { The production not } \\
\text { suitable/less }\end{array}$ & 25 \\
\hline 2 & Burnt/damaged & 5 \\
\hline 3 & Traders profit & 10 \\
\hline 4 & Payed in installments & 30 \\
\hline 5 & $\begin{array}{c}\text { Production of new lots } \\
\text { of pay off }\end{array}$ & 25 \\
\hline 6 & $\begin{array}{c}\text { There is a family } \\
\text { connection }\end{array}$ \\
\hline
\end{tabular}

The impact of debt bondage system on farmers' income

Table 5: Benefits of bonded labor system on farmers.

\begin{tabular}{|c|c|c|c|}
\hline No & Component & Unit & Amount (\%) \\
\hline 1 & Amont bondage & $\mathrm{Kg}$ & 134.75 \\
\hline 2 & Year bondage & year & $2,010.95$ \\
\hline 3 & $\begin{array}{l}\text { Long-duration } \\
\text { debt bondage }\end{array}$ & year & 5.05 \\
\hline \multirow[t]{3}{*}{4} & Year refund & & \\
\hline & - $\quad$ Amount & $\mathrm{Kg}$ & 73.75 \\
\hline & $\begin{array}{c}- \\
\text { Percentage }\end{array}$ & percent & 54.99 \\
\hline 5 & $\begin{array}{c}\text { Download } \\
\text { current prices } \\
\text { ijon }\end{array}$ & $\mathrm{Rp}$ & 35,750 \\
\hline \multirow[t]{2}{*}{6} & $\begin{array}{c}\text { Submit } \\
\text { current prices } \\
\text { Boundage result }\end{array}$ & & \\
\hline & $\begin{array}{l}\text { Which must } \\
\text { returned }\end{array}$ & $\mathrm{Rp}$ & 96,025 \\
\hline 7 & $\begin{array}{c}\text { Total debt } \\
\text { bondagewere } \\
\text { taken farmers }\end{array}$ & $\mathrm{Rp}$ & $12,939.37$ \\
\hline \multirow[t]{2}{*}{8} & $\begin{array}{l}\text { Farmers losses } \\
\text { people who do } \\
\text { bonded }\end{array}$ & & \\
\hline & $\begin{array}{l}\text { Which has } \\
\text { been repid }\end{array}$ & $\mathrm{Rp}$ & $4,817,312.50$ \\
\hline \multirow[t]{4}{*}{9} & - Unpaid & & \\
\hline & & $\mathrm{Rp}$ & $8,122,056.25$ \\
\hline & & $\mathrm{Rp}$ & $4,466,318.73$ \\
\hline & & $\mathrm{Rp}$ & $3,655,737.52$ \\
\hline
\end{tabular}

Indicators of the impact of this system is a strategic information for each farmer as it relates to the value of the loss caused by the small value of return. As seen in Table 5 shows that the volume is quite large because of generally amounted to $134.75 \mathrm{~kg}$ or greater than $100 \mathrm{~kg}$ were taken between 2012 to 2013 ago. Newly restored volume reached $73.75 \mathrm{~kg}$ or with new proportions reached $54.99 \%$ with a grace period of a maximum of 5 years has fully repaid the predictions and expectations of farmers. The magnitude of the price of what happens when a return of Rp.96,025/kg dry. This figure is relatively far in value compared to the value of the deal happens when bonded only priced at Rp.35.750/kg dry. Overall it can be said that the value of the transaction when bonded done only Rp.4,817,312.5 whereas an obligation that must be returned to Rp.12,939,368 or in other words, farmers suffered losses reached Rp.8,122,056.25 (as well as traders' profits) are distributed each are: already paid Rp. 4,466,318.73 while unpaid (up to 5 years ahead) of Rp.3,655,737.52 [10-14].

\section{Conclusion}

a. The cause of bonded labor system at the farm level is the productive cycle, farmers' lack of funds to finance farming, relatively high maintenance costs as well as costs of urgency needs of school children especially in the beginning of the new school/college or religious holidays. The amount of bonded labor is determined by the length of time the next harvest or with indicators of the condition of the ovaries.

b. Great value losses experienced by farmers is Rp.8,122,056.25 per harvest period.

\section{Suggestion}

Attention is needed in the form of the policy of the local government in helping to providing capital for farmers who really needed to finance the operational cost of harvesting is best done alone by the Government through the relevant agencies and institutions/offices/entities competent as cooperatives and farmer groups that return is performed after the harvest takes place with no interest or interest, but has a repayment scheme with the financing are clear, but not burden the clove farmers.

\section{References}

1. (2017) Prospects for Agricultural Development da Directions Clove (Second edition). Agency for Agricultural Research and Development. Agriculture department.

2. (2016) Cloves prospects. Promising.

3. Mamonto (2012) Feasibility Analysis of Crop Farming in Cloves (Eugenia Aromatica) in District Nuangan (Case Study in the village of the District Matabulu Nuangan). Skripsi, Universitas Nusantara, Indonesia.

4. Danarty (1993) Cultivation and Post Harvest Handling Clove. Publisher Governmental Jakarta.

5. de Lin BC, Claudio AQ, Edsandra O, Francisco C, Maia C, et al. (2016) Anesthetic and anthelminthic effects of clove basil (Ocimum gratissimum) essential oil for tambaqui (Colossoma macropomum). 457(20): 24-28.

6. Behera UK, France J (2016) Integrated Farming Systems and the Livelihood Security of Small and Marginal Farmers in India and Other Developing Countries. Advances in Agronomy 138: 235-282. 
7. Clove Miraculous Benefits For Health.

8. Sondakh J (2014) Indigenous Agreement "Ijon Cloves" Relevance and challenge the Customary Law Enforcement in Indonesia (Scientific) Faculty of Law, University of Sam Ratulangi, Manado.

9. Taulu CH (1997) Minahasa history. Printing of North Sulawesi Province, p. 32.

10. (2016) Anesthetic and anthelminthic effects of clove basil (Ocimum gratissimum) essential oil for tambaqui (Colossoma macropomum). 457: $24-28$

11. (2017) Indonesia Dictionary.
12. Cloves Start Stable prices, this causes

13.(2007) Research and Development Center of Plantation. Cloves Featured Technology Supporting Cultivation and Varieties. Booklet 2-5.

\section{Your next submission with Juniper Publishers will reach you the below assets}

- Quality Editorial service

- Swift Peer Review

- Reprints availability

- E-prints Service

- Manuscript Podcast for convenient understanding

- Global attainment for your research

- Manuscript accessibility in different formats ( Pdf, E-pub, Full Text, Audio)

- Unceasing customer service

Track the below URL for one-step submission https://juniperpublishers.com/online-submission.php 